\title{
COMBUSTION CHARACTERIZATION OF PRODUCER GAS FROM BIOMASS GASIFICATION
}

\section{J.J. HERNÁNDEZ* \\ J. BARBA \\ G. ARANDA}

Received: 02/12/11

Accepted: 09/03/12

\author{
Universidad de Castilla- La Mancha \\ Departamento de Mecánica Aplicada e Ingeniería de Proyectos \\ Avenida Camilo José Cela, S/N, 13071 Ciudad Real, Spain
}

*to whom all correspondence should be addressed: e-mail: JuanJose.Hernandez@uclm.es

\section{ABSTRACT}

In the present work, premixed flames from the combustion of producer gas have been analyzed. Two different compositions have been tested, corresponding to air and steam gasification processes (the latter leading to a better quality gas due to its higher $\mathrm{CO}$ and $\mathrm{H}_{2}$ concentration and its lower $\mathrm{N}_{2}$ content). The main objectives of the work have been the determination of the flame stability region (placed between the flashback and the blowoff limits) for each producer gas composition, as well as the study of the $\mathrm{OH}$ and $\mathrm{CH}$ radicals. The combustion experimental tests have been carried out by using an atmospheric burner and a chemiluminescence camera.

The results obtained show that producer gas coming from biomass entrained-flow steam gasification seems to be more adequate to be used in combustion systems, since it provides a larger flame stability region, and its blowoff limit for a given relative producer gas/air ratio is higher (which enable to obtained more power). From the study of $\mathrm{CH}$ and $\mathrm{OH}$ radicals, it can be deduced that it is possible to reduce the nitrogen oxides emissions up to 18.6 and $15.2 \%$ with producer gas from steam gasification and air gasification respectively by using lean mixtures (while keeping the flame stability).

KEYWORDS: Producer gas, flame stability region, flashback, blowoff, $\mathrm{OH}$ and $\mathrm{CH}$ radicals.

\section{INTRODUCTION}

The diversification of the energy sources has become one of the main objectives of governments due to drawbacks associated to the consumption of fossil fuels such as depletion, price volatility, dependence on foreign countries and pollutant emissions. All these problems have led to the development of energy policies in many countries, including Spain, in order to encourage and promote clean energy. One of the main points of these policies focuses on renewable energies, among which is included biomass, whose main advantages are the economic and social development of rural areas, an alternative to waste management, and the reduction of $\mathrm{CO}_{2}$ emissions.

Gasification is considered as a promising technology for the energy use of biomass. It consists of a thermochemical process during which a series of reactions in an oxygen-poor environment at high temperatures take place, resulting in the conversion of a carbonaceous solid fuel into a fuel gas (called producer gas or syngas depending on the product composition), which may be used to produce heat or electricity in boilers, turbines, internal combustion engines or fuel cells, or as feedstock for the synthesis of fuels and chemicals.

Gasification appears as an attractive alternative to direct combustion since it allows the reduction of storage and transportation costs by means of the installation of small and efficient gasifier-engine systems (Hernandez et al., 2010), as well as the recovery of available energy from low-value (biomass wastes and low-rank coals) materials, thereby reducing both the environmental impact and the disposal costs. Gasification is considered as a cleaner and more efficient technology than combustion, since it enables higher electrical efficiencies both at lower power outputs (30-32 \% by 
using gas engines compared to $22 \%$ achieved with a conventional Rankine cycle (IDEA webpage, 2011) and at higher power productions (via IGCC cycles), lower $\mathrm{NO}_{\mathrm{x}}$ and $\mathrm{SO}_{\mathrm{x}}$ emissions and possibility of $\mathrm{CO}_{2}$ capture.

The gasification producer gas is composed mainly of $\mathrm{H}_{2}, \mathrm{CO}, \mathrm{N}_{2}, \mathrm{CO}_{2}, \mathrm{CH}_{4}, \mathrm{H}_{2} \mathrm{O}$ and traces of other hydrocarbons. Unfortunately, pollutants such as particles, tar, ammonia and alkaline metals may also be found in the gas in variable quantities. The composition of the producer gas is highly variable depending on the type of gasifier, the type of biomass, the operating conditions (temperature, pressure, relative fuel/gasifying agent ratio, fuel particle size, use of catalysts, etc.), and the type of gasifying agent used in the process (mainly air, oxygen, steam or a mixture of them).

Air gasification is the most economical option, and allows an autothermal operation. However, the producer gas obtained has a low heating value $\left(<6 \mathrm{MJ} \mathrm{m}^{-3}\right)$ due to the dilution in $\mathrm{N}_{2}$. On the other hand, steam gasification leads to higher $\mathrm{H}_{2}$ content in the producer gas, so it is a feasible alternative for hydrogen production from biomass. However, it is necessary to provide heat externally to the process.

Previously to the efficient use of the producer gas in combustion systems, it is necessary to carry out detailed studies about flame stability region in order to avoid flame extinction and to ensure a smooth and reliable operation in combustion devices regardless of the gasifying agent used and the resulting gas composition. A flame is reported to be stable when there is a balance between the reactants velocity and the laminar burning velocity. When an imbalance between both velocities occurs, instability phenomena such as blowoff and flashback appear. The former (reactants velocity exceeding the laminar burning velocity) refers to situations where the flame becomes detached from the location where it is anchored and is physically "blown out" of the combustor (Ruey-Hung et al., 2005). Flashback (laminar burning velocity exceeding the reactants velocity) occurs when the flame propagates upstream of the region where it is supposed to be anchored and into premixing passages that are not designed for high temperature (Lieuwen et al., 2008). Blowoff is a concern in low emissions combustors that often operate very near the blowoff limits, whereas flashback is an issue with high laminar burning velocities fuels, such as those containing high hydrogen levels (Noble et al., 2006).

In this work, $\mathrm{CH}$ and $\mathrm{OH}$ radicals in the combustion process have been studied due to its great interest for combustion analysis, especially in $\mathrm{NO}_{x}$ emissions. $\mathrm{OH}$ radicals are intermediate and very active compounds generated during the combustion process in the reaction zone by the dissociation of $\mathrm{H}_{2} \mathrm{O}_{2}$ at high temperatures. Some examples of the importance derived from the study of $\mathrm{OH}$ radicals are shown in the work of Bouvet et al. (2010), where the laminar burning velocity is calculated measuring the entire surface of the flame (through $\mathrm{OH}$ chemiluminiscence) and applying mass conservation balance, or in the work of Schefer et al. (2008), who suggest that a higher concentration of radicals reduces the emissions of $\mathrm{CO}$ since they complete the oxidation from $\mathrm{CO}$ to $\mathrm{CO}_{2}$. On the other hand, it has also been studied the $\mathrm{CH}$ radicals during the combustion process, since they are a good indicator of the local relative fuel/air ratio, a very important parameter in gas engines. In addition, the study of these radicals can diagnose the formation of $\mathrm{NO}_{\mathrm{x}}$ (Sepman et al., 2008), since the $\mathrm{OH}$ radical is the only indicator of the formation of NO by the Zeldovich mechanism and the $\mathrm{CH}$ radical is involved in the initial reaction of the Fenimore mechanism.

\section{EXPERIMENTAL SETUP}

The combustion tests performed for this work have been carried out at the combustion pilot plant of the Fuels and Engines Group of the University of Castilla-La Mancha. The facility (Figure 1) consists mainly of an atmospheric burner and a chemiluminescence camera.

The gas burner is an atmospheric Bunsen burner which has a flame stabilization unit. It consists of a gas inlet, a compressor for the air intake and two rotameters with their respective flow control valves (for gas and air). Therefore, this unit is able to control in an effective way both the air and the producer gas flows, thereby regulating the relative producer gas/air ratio (which is defined with respect to the stoichiometric one) in each test. The burner has the limitation of the gas inlet pressure (between 12.3 and 36.8 mbar gauge for proper operation). In order to avoid working out of this range, a pressure regulator is used. The burner has four different nozzles, which allow studying the reactants velocity in a very wide region. 


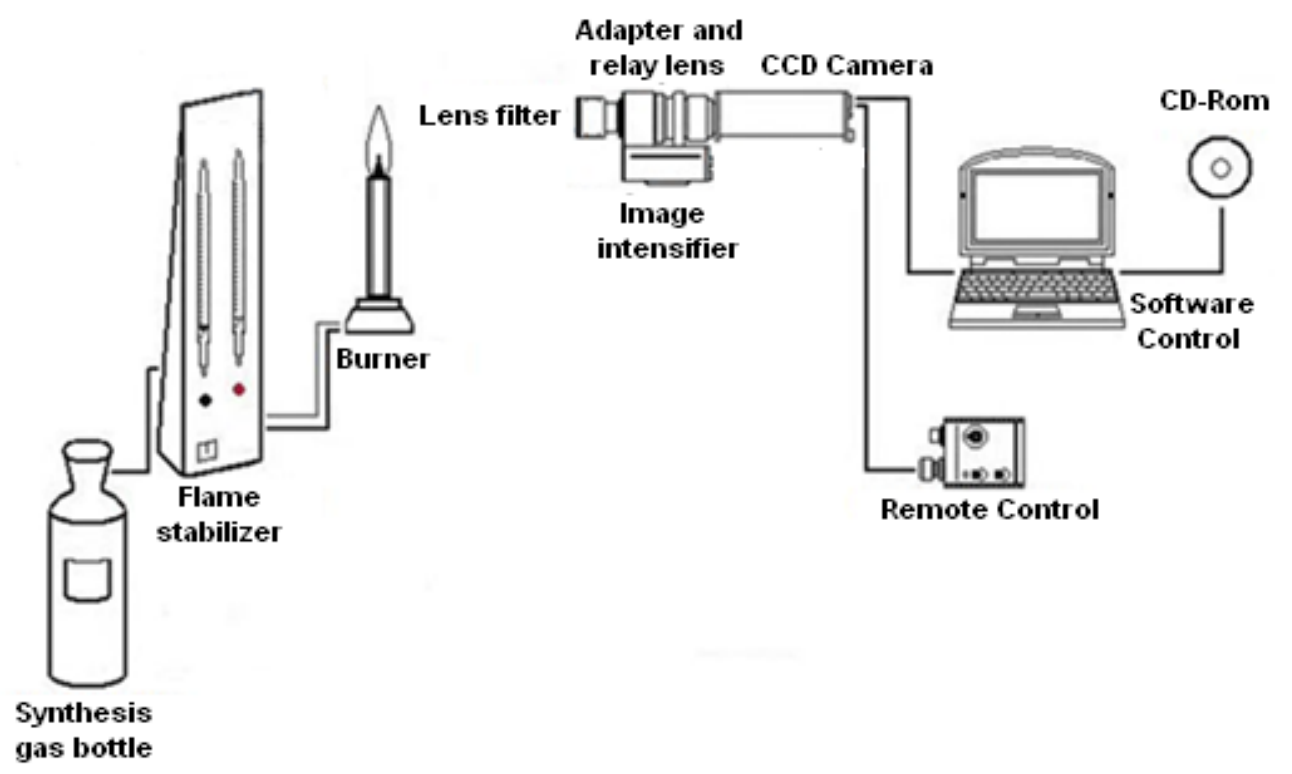

Figure 1. Gas combustion pilot plant

In this work, a CCD (charge-coupled device) camera connected to an image intensifier through a relay lens has been used. Chemiluminescence is a technique that consists of detecting the light intensity emitted by the flame at each point in a particular area. For this purpose, tests must be carried out in a completely dark room in order to avoid the presence of light sources apart from the light intensity derived from the flame. If no filter is used, the camera detects all the light intensity emitted by the flame. However, there are filters available (which must be placed in front of the camera lens before beginning the tests) in order to capture only the radiation emitted by each one of the radicals. In this case, the appropriate detection wavelengths are $308 \mathrm{~nm}$ for $\mathrm{OH} \bullet$ and $432 \mathrm{~nm}$ for $\mathrm{CH} \cdot$. Once the flame is stable, ten photographs are taken in which the light intensity emitted by the flame can be observed. Finally, a mean value of the intensity obtained in the photographs is calculated in order to obtain the data.

\section{MATERIALS}

Two different producer gases have been tested, both of them coming from biomass gasification tests performed in an entrained-flow gasification pilot plant (described elsewhere (Hernandez et al., 2010) using dealcoholised marc of grape (an abundant biomass solid waste in the southern regions of Europe) as fuel. Both tests were carried out at similar operating conditions, but changing the gasifying agent (air or steam). Table 1 shows the experimental conditions of the gasification tests.

After gasification tests, the compositions obtained were simulated in synthetic bottles with two main objectives. On the one hand, in order to to keep constant both the gas composition and the flow rate (thus avoiding uncertainties in the combustion tests) and, on the other hand, in order to extend the useful life of the unit stabilization (since the producer gas does not contain troublesome pollutants such as tars).

In Table 1, the subscript $f$ denotes the solid fuel, daf the fuel in a dry, ash-free basis, $a$ the air and $s$ the steam. On the other hand, $A / B$ and $S / B$ refers to the air/biomass and steam/biomass ratios respectively; $t_{r}$ the space residence time, Frg the relative biomass/air ratio (defined with respect to the stoichiometric one), and $L H V$ is the lower heating value of the producer gas.

\section{RESULTS AND DISCUSSION}

\subsection{Combustion of producer gas using steam as gasifying agent}

In order to study the reactants velocity and the laminar burning velocity independently, it is necessary to use a stability diagram, which represents the reactants velocity versus the relative fuel/air ratio (which is directly related to laminar burning velocity). The stability diagram of the 
producer gas obtained from steam gasification is displayed in Figure 2. The circles represent the experimental tests carried out, whereas the dashed line is the boundary of each phenomenon.

Table 1. Operating conditions of the gasification tests

\begin{tabular}{|c|c|c|}
\hline \multirow{2}{*}{ Operating conditions } & \multicolumn{2}{|c|}{ Gasifying agent } \\
\hline & Air & Steam \\
\hline$T\left({ }^{\circ} \mathrm{C}\right)$ & & \\
\hline$m_{f}\left(\mathrm{~kg} \mathrm{~h}^{-1}\right)$ & 1.35 & 1.21 \\
\hline$m_{f, d a f}\left(\mathrm{~kg} \mathrm{~h}^{-1}\right)$ & 1.15 & 1.03 \\
\hline$m_{a}\left(\mathrm{~kg} \mathrm{~h}^{-1}\right)$ & 2.08 & - \\
\hline$m_{s}\left(\mathrm{~kg} \mathrm{~h}^{-1}\right)$ & - & 1.5 \\
\hline$A / B$ & 1.53 & - \\
\hline$S / B$ & - & 1.24 \\
\hline $\mathrm{t}_{\mathrm{r}}(\mathrm{s})$ & 1.57 & 1.38 \\
\hline Frg & 3.79 & - \\
\hline Producer gas composition & & \\
\hline $\mathrm{N}_{2}$ & 55 & 7 \\
\hline $\mathrm{CO}$ & 16 & 28 \\
\hline $\mathrm{H}_{2}$ & 11 & 26 \\
\hline $\mathrm{CH}_{4}$ & 3 & 13 \\
\hline $\mathrm{CO}_{2}$ & 15 & 19 \\
\hline $\mathrm{C}_{2} \mathrm{H}_{6}$ & - & 7 \\
\hline$L H V\left(\mathrm{MJ} \mathrm{Nm}^{-3}\right)$ & 4.28 & 15.69 \\
\hline
\end{tabular}

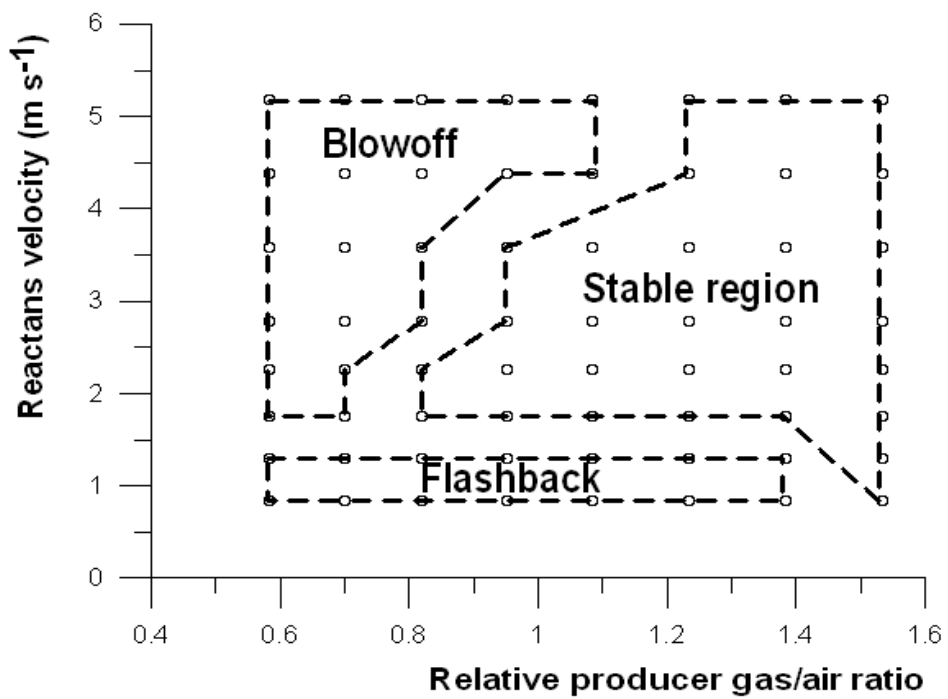

Figure 2. Flame stability diagram of the producer gas obtained from steam gasification

In order to obtain a stable flame, the laminar burning velocity $\left(\mathrm{V}_{\text {flame }}\right)$ must be equal to the perpendicular component of the reactants velocity $\left(V_{p}\right.$,reactants $)$ (Schefer et al., 2008; Glassman, $1987)$, as shown in Figure 3 . For this reason, reactants velocity ( $\left.\mathrm{V}_{\text {reactants }}\right)$ where the flame stability region is achieved (which is plotted in Figure 2) is higher than the laminar burning velocity shown in Figure 4 (calculated with CHEMKIN PRO (CHEMPKIN PRO, manual, 2010), since the mentioned perpendicular component of the reactant velocity is much lower than the reactants velocity. On the other hand, points which do not belong to any region of the diagram might be points not analyzed due to lack of accuracy, or points not very clearly defined.

As can be observed in Figure 2, stable operation can be achieved for lean mixtures with relative producer gas/air ratios ranging from 0.82 to 1 (the maximum reactants velocity allowed being 1.75 and $2.78 \mathrm{~m} \mathrm{~s}^{-1}$ respectively). The use of lean relative producer gas/air ratios allows the reduction of the emission of nitrogen oxides (NOx) and a more efficient combustion process. 
The two lowest reactants velocities tested $\left(0.84\right.$ and $\left.1.29 \mathrm{~m} \mathrm{~s}^{-1}\right)$ make up the flashback region as can be seen in Figure 2. This behavior is normal since the reactants velocity is always lower than the laminar burning velocity regardless of the relative producer gas/air ratio (except for the richest point where the laminar burning velocity is very low due to the high relative producer gas/air ratio).

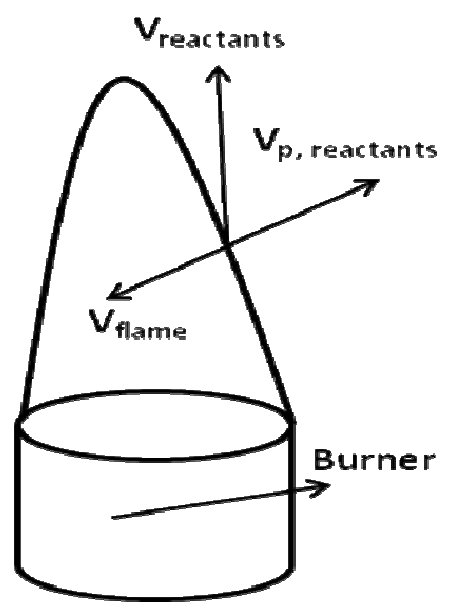

Figure 3. Characteristics velocities in a burner flame

The blowoff limit for a given relative producer gas/air ratio is relatively high (for example, for a relative producer gas/air ratio near 1 , the blowoff limit is about $4.2 \mathrm{~m} \mathrm{~s}^{-1}$ ), which is an advantage since it enables to introduce higher mixture flow rates, thus increasing the power. This phenomenon is explained by the high laminar burning velocity of the fuel (due both to its high hydrogen content and its low inert content), since the more laminar burning velocity, the more mixture flow rate is necessary to achieve the balance. The laminar burning velocity is shown in Figure 4.

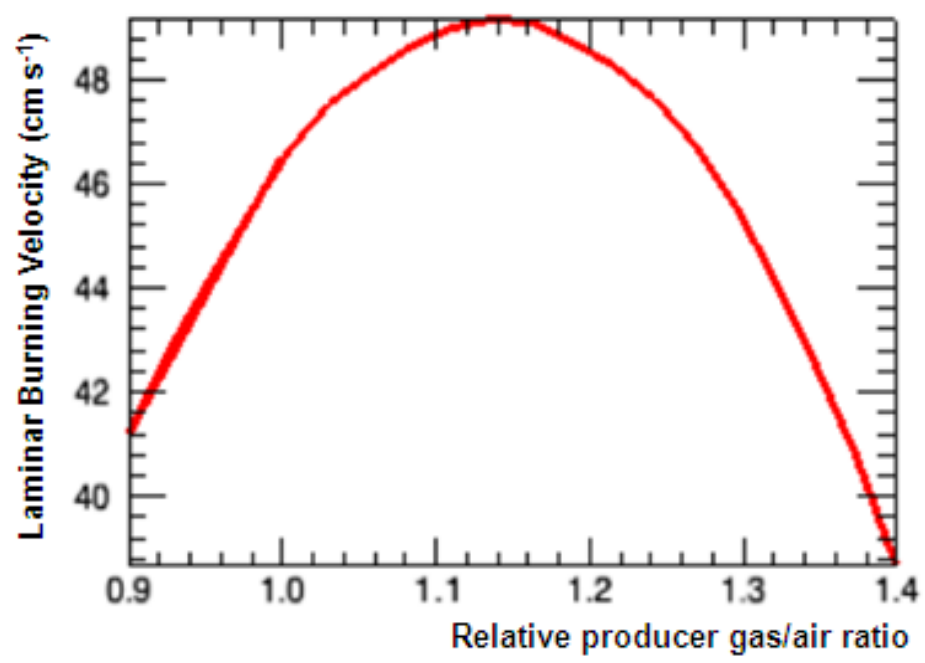

Figure 4. Effect of the relative producer gas/air ratio on the laminar burning velocity for a producer gas obtained from steam gasification

The measurement of $\mathrm{CH}$ and $\mathrm{OH}$ radicals enable to detect the amount of these radicals in the flame, mostly present in the reaction zone of the premixed cone. Chemiluminescence tests give as result the experimental points of light intensity in arbitrary units (directly related to $\mathrm{OH}$ and $\mathrm{CH}$ radicals emissions) versus relative producer gas/air ratio. Then, these points are fitted by polynomial curves. The results obtained are shown in Figure 5.

From the results shown in Figure 5, it is possible to determine the reduction of $\mathrm{NO}_{x}$ emissions generated during the combustion process depending on the relative producer gas/air ratio used. For a relative producer gas/air ratio about 1.1, the amount of $\mathrm{NO}_{x}$ emissions generated is maximum whereas the minimum amount of $\mathrm{NO}_{x}$ emissions is reached for a relative producer gas/air ratio about 0.82 (this value belongs to the leaner stable point). The reduction achieved between the maximum and the minimum amount of $\mathrm{NO}_{x}$ emissions generated is about $18.6 \%$. 
As shown in the Figure 5, the maximum amount of both radicals is reached for relative producer gas/air ratios slightly richer $(\sim 1.1)$ due to the product dissociation (Law et al., 2006). This value presents an error lower than $5 \%$ in relation with the relative producer gas/air ratio at which the peak of the adiabatic flame temperature is reached $(\approx 1.04)$ as shown in Figure 6.

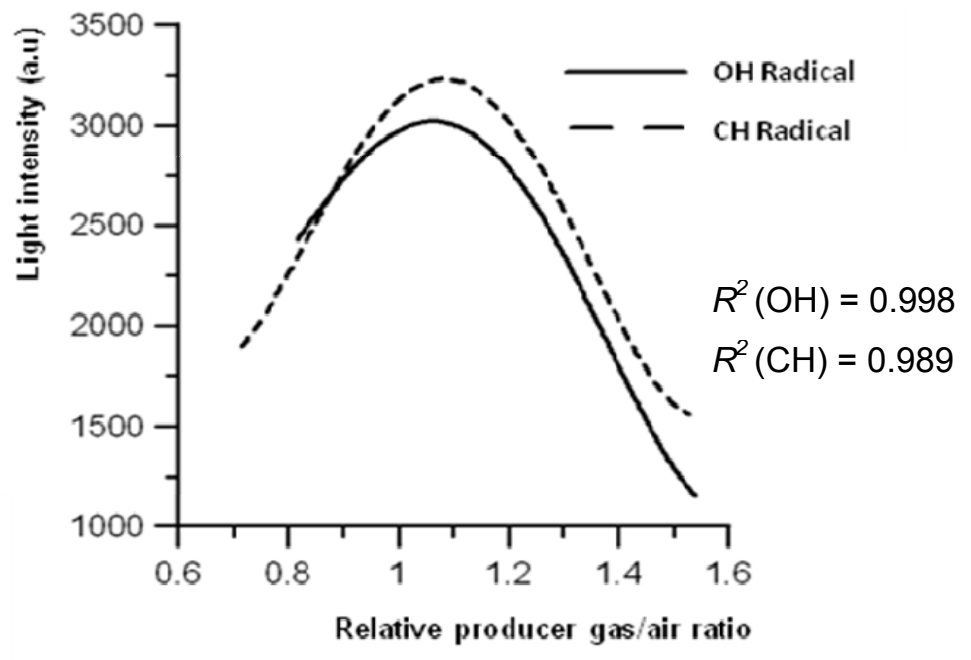

Figure 5. Emission of $\mathrm{OH}$ and $\mathrm{CH}$ radicals in the combustion of producer gas obtained from steam gasification versus relative producer gas/air ratio

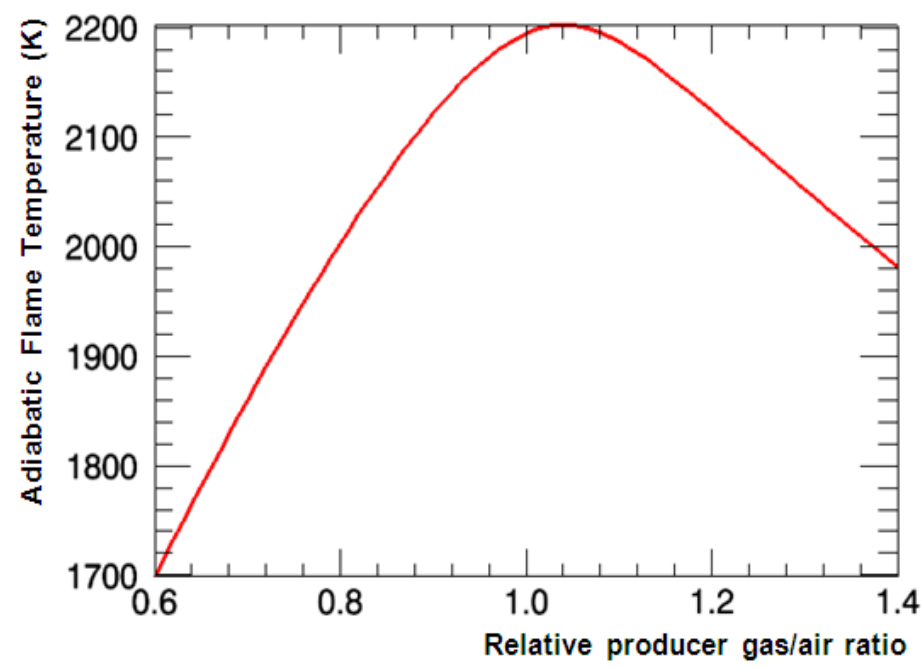

Figure 6. Adiabatic flame temperature versus relative producer gas/air ratio for a producer gas obtained from steam gasification

\subsection{Combustion of producer gas using air as gasifying agent}

The stability diagram of the producer gas obtained from air gasification is shown in Figure 7 . The circles represent the experimental tests carried out, whereas the dashed line is the boundary of each phenomenon.

As can be observed, there is a region of stability in the lean area (relative producer gas/air ratio $<1$ ) which enables to operate with lean mixtures for relative producer gas/air ratios from 0.79 to 1 (the maximum reactants velocity allowed being 0.5 and $0.71 \mathrm{~m} \mathrm{~s}^{1}$ respectively).

In this diagram, the flashback region is smaller than that obtained for steam gasification. This is because the producer gas obtained using air as gasifying agent presents a high inert content of $\mathrm{N}_{2}$ and $\mathrm{CO}_{2}$ (approximately $70 \%$ vol.), and therefore the peak laminar burning velocity is reached for lower relative producer gas/air ratio values.

The blowoff limit for a given relative producer gas/air ratio is relatively low (for example, for a relative producer gas/air ratio near 1 , the blowoff limit is about $1.25 \mathrm{~m} \mathrm{~s}^{-1}$ ), which is a disadvantage since it 
does not enable to introduce high mixture flow rates, and consequently the power decreases. This phenomenon can be explained by the low laminar burning velocity of the fuel (due to its high inert content), since the less laminar burning velocity, the less mixture flow rate is necessary to achieve the stability.

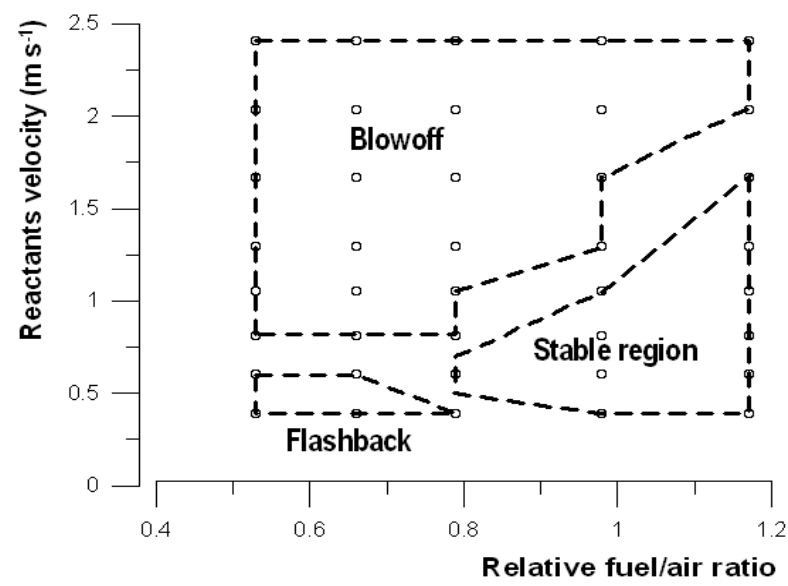

Figure 7. Flame stability diagram of the producer gas obtained from air gasification

The study of $\mathrm{OH}$ and $\mathrm{CH}$ radicals has also been carried out in the case of producer gas from air gasification. Trends are similar to those obtained for producer gas from steam gasification, although there are some differences such as the peak in which the amount of radicals are maximum (at a relative producer gas/air ratio about 1.0) and the slope of the parabola. The results obtained are shown in Figure 8.

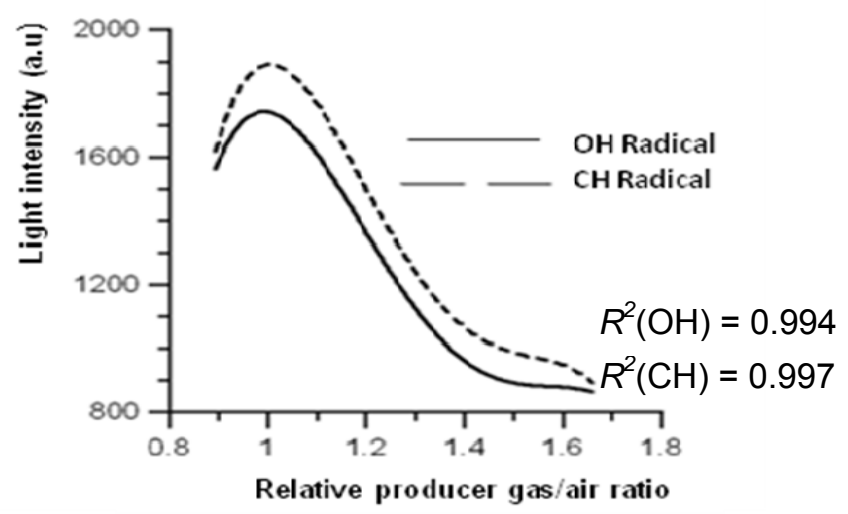

Figure 8. Emission of $\mathrm{OH}$ and $\mathrm{CH}$ radicals in the combustion of producer gas obtained from air gasification versus relative producer gas/air ratio

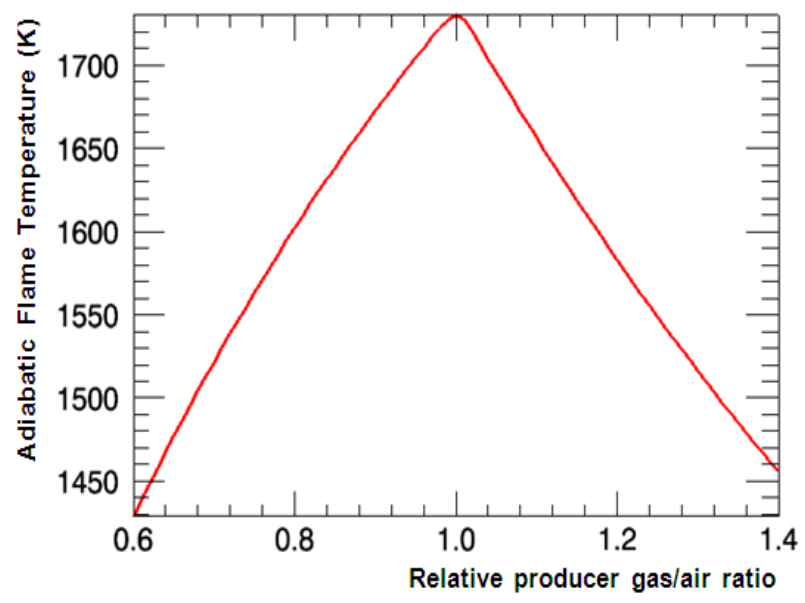

Figure 9. Adiabatic flame temperature versus relative producer gas/air ratio for a producer gas obtained from air gasification 
For a relative producer gas/air ratio about 1.0, the amount of $\mathrm{NO}_{x}$ emissions generated are maximum, whereas the minimum amount of $\mathrm{OH}$ and $\mathrm{CH}$ radicals is reached for a relative producer gas/air ratio about 0.79 (this value belongs to the leaner stable point). The reduction achieved between the maximum and the minimum amount of $\mathrm{NO}_{x}$ emissions is about $15.2 \%$.

The maximum amount of both radicals is reached for a relative producer gas/air ratio near 1.0, which is consistent with the adiabatic flame temperature of the fuel, as can be seen in Figure 9.

\section{CONCLUSIONS}

Premixed flames from the combustion of producer gas obtained from biomass gasification using air and steam as gasifying agent have been analyzed. The main advantages of using steam instead of air as gasifying agent from the combustion point of view are the following:

- Larger flame stability region.

- Higher blowoff limit for a given relative producer gas/air ratio. Therefore, more power can be achieved.

Results related to chemiluminescence are the following:

- The maximum amount of $\mathrm{OH}$ and $\mathrm{CH}$ radicals generated in the combustion of the producer gas obtained has been obtained for a relative producer gas/air ratio about 1.1 and 1 for steam gasification and air gasification respectively. These values are consistent with the maximum adiabatic flame temperature of the fuels.

- By using lean mixtures while keeping the combustion stability, It is possible to reduce the nitrogen oxides emissions up to $18.6 \%$ using producer gas from steam gasification (corresponding to a relative fuel/air ratio of 0.82 ), whereas using air gasification producer gas the reduction of NOx is $15.2 \%$ (corresponding to a fuel/air ratio of 0.79 ).

\section{ACKNOWLEDGEMENTS}

The Ministry of Education and Science of the Government of Castilla-La Mancha is gratefully acknowledged for their financial support through the GENERBIO Research Project (Reference POII100128-1789)

\section{REFERENCES}

Bouvet N., Chauveau C., Gökalp S., Lee Y. and Santoro R.J. (2010), Characterization of syngas laminar flames using the Bunsen burner configuration, International Journal of Hydrogen Energy, 36, 9921005.

CHEMKIN-PRO 15101, Reaction Design: San Diego, 2010.

Glassman I. (1987), Combustion, Second edition, Academic Press, Orlando.

Hernández J.J., Aranda G. and Bula A. (2010), Gasification of biomass wastes in an entrained flow gasifier: Effect of the particle size and the residence time, Fuel Processing Technology, 91, 681-692.

IDAE, Ministerio de Industria, Turismo y Comercio, Gobierno de España, Biomasa: http://www.idae.es/index.php/mod.publicaciones/mem.detalle/relmenu.73/id.35, last accessed February 2011.

Law C.K., Makino A. and Lu T.F. (2006), On the off-stoichiometric peaking of adiabatic flame temperature, Combustion and Flame, 145, 808-819.

Lieuwen T., McDonell V., Santavicca D. and Sattelmater T. (2008), Burner development and operability issues associated with steady flowing syngas fired combustors, Combustion and science technology, 180:60, 1169-1192.

Noble D., Zhang Q., Shareef A., Tootle J., Meyers A. and Lieuwen T. (2006), Syngas mixture composition effects upon flashback and blowout, Proceedings of GT2006 ASME Turbo Expo: Power for Land, sea and air.

Ruey-Hung C., Kothawala A., Chaos M. and Chew L. (2005), Schmidt number effects on laminar jet diffusion flame liftoff, Combustion and flame, 141, 469-472.

Schefer R.W., White C. and Keller J. (2008), Lean Combustion, First Edition, Elsevier, Irvine.

Sepman A.V., Van Essen V.M., Mokhov A.V. and Levinsky H.B. (2008), The effects of hydrogen addition on Fenimore NO formation in low-pressure, fuel-rich premixed, burner-stabilized $\mathrm{CH} 4 / \mathrm{O} 2 / \mathrm{N} 2$ flames, International Journal of Hydrogen Energy, 33, 5850-5827. 